\title{
Effect of puff drying on seedless grape fruits quality criteria compared to convective air drying
}

\author{
M. M. Abul-Fadl ${ }^{1}$, T. H. Ghanem ${ }^{2}$, N. EL-Badry ${ }^{1}$ and A. Nasr ${ }^{1, *}$ \\ ${ }^{1}$ Department of Food Science and Technology, Faculty of Agriculture, Al-Azhar University. Cairo, Egypt \\ ${ }^{2}$ Department of Products Process Engineering, Faculty of Agricultural Engineering, Al-Azhar University, \\ Cairo, Egypt
}

*Corresponding author email: aliq11150@azhar.edu.eg (A. Nasr)

\begin{abstract}
The goal of the present study is to investigate the effect of explosion puffing and convection air drying on the physical, chemical and sensory properties of dried seedless grape, and cost of operation. The obtained results showed that, the drying rate of puff drying method (PD) was faster than that of convection air drying method at the corresponding drying condition of $\left(60^{\circ} \mathrm{C}\right.$ and $1.5 \mathrm{~m} / \mathrm{s}$ air velocity). The seedless grape samples dried by PD were the best for the most of physico-chemical quality properties such as color index, texture, rehydration ratio, and shrinkage rate compared to similar samples dried by $\mathrm{AD}$ that required a longer time. The seedless grape dried by PD method had the highest amount of total phenolic compounds $(276.73 \mathrm{mg} / 100 \mathrm{~g} \mathrm{DM})$ than that in convection air drying. The highest value of total carotenoids $(84.44 \mathrm{mg} / 100 \mathrm{~g} \mathrm{DM})$ was found in seedless grape dried by PD method. The PD drying process led to retention of total flavonoids in dried seedless grape samples at a wide rate depending on the drying time compared to the AD drying methods. The PD technique exhibited the ability to obviously quench the DPPH radical compared to the AD method. In conclusion, the seedless grape samples dried by PD exhibited good sensory properties and better acceptability. PD can meet the four major requirements in drying foods: short time of operation, energy efficiency, cost of operation, and quality of dried products which indicates that puff drying is a good choice for grape processing.
\end{abstract}

Keywords: Explosion puff drying; air drying; color index; texture; sensory quality.

\section{INTRODUCTION}

There is an increasing market demand for dehydrated fruits and vegetables worldwide Zhang et al. (2006). The major objective of drying agricultural products is the reduction of the moisture content to a level, which allows safe storage over an extended period. Up to now, many methods have been used successfully to dry different food materials, but each drying technique has its own advantages and drawbacks (Viswanathanl et al. 2003). Conventional drying methods, such as air-drying results in low drying rates, especially in the falling rate period of drying Wang et al. (2007).

In addition to these problems, the conventional drying methods also have drawbacks of high energy requirements, loss of color and nutritional properties due to longer exposure to heat, and cause hardening of the surface Wang et al. (2014). As compared to the above-mentioned methods, freeze drying is a particular method. Though it is a time-consuming and high energy-consuming process, it can maximally preserve the original properties such as hydration, flavor, activity, and the shape wanted Liu et al., (2015).
The most common method used for drying is hot air drying, however, this method has many disadvantages to handle large quantities and to achieve consistent quality standards, contamination problems, long drying times, low energy efficiency and high cost. It may also cause serious damage to product flavor, color and nutrients, reducing bulk density and rehydration capacity that is not desirable for the food industry (Soysal and Oztekin, 2001).

During hot air drying the surface temperature of the samples is higher than their internal temperatures. As the moisture on the surface of sample evaporates, the sample surface may easily form a hard shell that resists transfer of the internal moisture to the surface. This phenomenon causes a moderate, but long shrinkage time, which is considered to be the factor responsible for the higher shrinkage of air drying (Wang et al., 2014).

Explosion puff drying contributes to a typical porous structure and an appealing crispy texture, which is one of the most important qualities for fruit chips. Other favorable characteristics of the EPD finished product are found in flavor, color and rehydration, as well as competitive production costs (Du et al., 2013). 
A relatively new process that has been applied successfully to several different fruits and vegetables is explosion puff-drying. This process is accomplished by exposing a relatively small piece of product to high pressure and high temperature for a short time, after which the product is moved to atmospheric pressure. This results in flash evaporation of water vapors from the interior parts of the product to escape. Products produced by puff-drying have very high porosity with rapid rehydration characteristics. Puff-drying is particularly effective for products with significant falling-rate drying periods. The rapid moisture evaporation and resulting product porosity contribute to rapid moisture removal during the final stages of drying. The puff-drying process is accomplished most efficiently by using $2-\mathrm{cm}$ cube shapes. These pieces will dry rapidly and uniformly and will rehydrate within 15 minutes. Although the process may not have applications for all foods, the superior quality encourages additional investigation of the process. (Singh and Heldman, 2009).

The added advantage of this is quick drying, reduction in shrinkage and, hence, the porous structure of samples was is well maintained. However, the delicious and crispy products are obtained. Chips have become increasingly popular in the diet of modern consumer due to a pleasant mouth feel (Zou et al., 2013).

The present investigation was carried out to fulfill the following objectives:

- Showing the effect of the recent drying method (puff drying) as compared to convection air drying on:

The drying kinetics such the falling rate period (elapsed time), drying curves, drying rate of dried seedless grape.

Determine the optimal conditions for drying seedless grape that were selected depending on rehydration time.

Effect of puff drying compared to convection air drying on the falling rate period of moisture content (\%) for the production of dried seedless grape

Estimate the effect of puff drying as compared to convection air drying on quality criteria such as physicochemical properties, antioxidant compounds, total antioxidant activity of dried fruits (grapes) produced.
The economical evaluation of convection air drying as compared to puff drying method for dried seedless grape.

\section{Material and Methods}

Samples of seedless grape fruits used in this investigation were grapes (Vitis vinifera L.) Thompson seedless variety was obtained from Giza Governorate, Egypt. Fresh seedless grape used in this study was uniform size (average radius, length, and weight). The Grape was washed with tap water and dipped in a hot alkaline solution $(0.5 \mathrm{~g} \backslash \mathrm{L} \mathrm{NaoH})$ for $30 \mathrm{sec}$. at $90^{\circ} \mathrm{C}$, as well as after washing the seedless grape samples, to remove $\mathrm{NaOH}$ they were treated with sodium metabisulfite solution 1 $\mathrm{g} \backslash \mathrm{L}$ for $30 \mathrm{~min}$, and then drained and divided into equal 2 patches. Then the 2 patches carefully set up as a single layer. Each patch from the prepared seedless grape samples was dried as follows: Air convection drying (AD) and puff drying method (PD). The preparation of testing grape samples was, according to (Kassem et al., 2011).

\section{Drying methods:}

In the present study three consecutive drying methods were used namely:-

Oven drying method (used preliminary treatment).

Puff drying method (high pressure).

Vacuum drying method.

First, Preliminary drying treatment was carried out in the convection air dryer, parallel rectangles of $55 \times 60 \times 140 \mathrm{~cm}$, this first stage of drying was aimed to remove the free water of grapes by drying at $60{ }^{\circ} \mathrm{C}$ air speed of $1.5 \mathrm{~m} / \mathrm{s}$ for $6 \mathrm{~h}$. A-photograph, Fig. (1) showed the convective dryer used.

Second, the puff drying system was designed by the second author, professor of agricultural products, process engineering faculty Agricultural Engineering AL Azhar University- Cairo.

\section{The puff drying system was consisted of: -}

Puff dryer with a cylindrical shape oven of $50 \mathrm{~cm}$ diameter $60 \mathrm{~cm}$ long.

Pipes, valves and pressure gages.

Two cylindrical containers for vapor precipitation process.

Evacuation pumps for evacuation process and compressor for high pressure process. 
Configuration is presented in Fig (1) all products were dried in a puff dryer at $80^{\circ} \mathrm{C}$ and a pressure of $1,1.5$ and 2 bar. Pressure has suddenly dropped to atmospheric pressure with the aid of steam valves. The second puff drying process was aimed to allow vapors easily escape from the interior parts of products. Then it was suddenly dropped to the atmospheric pressure.

Third, drying process was continuously carried out at a vacuum pressure of -1 bar and $60^{\circ} \mathrm{C}$ for $230 \mathrm{~min}$. In the present study hot air drying or convective drying technique was used till the end of the constant rate period of drying. Preliminary experiments carried out proved that, six hours of elapsed drying time are required for depleting constant rate drying at $1.5 \mathrm{~m} / \mathrm{s}$ and $60^{\circ} \mathrm{C}$.

Puff drying technique was used to allow vapors from the interior parts of products to be easily escaped, drying was proceed at $80{ }^{\circ} \mathrm{C}$ and 1, 1.5 and 2 bars for 5, 10 and 15 minutes, to study the effect of pressure and elapsed time on product quality. Drying processes were continuously occurred in a vacuum dryer at $60{ }^{\circ} \mathrm{C}$ and -1bar till recommended safe storage moisture content of grape was satisfied. Rehydration technique was also used for selecting optimal drying conditions.

\section{Chemicals, reagents used:}

All chemical reagents used in the present study were analytical grade. Folin-Ciocalteu, Gallic acid, all chemicals were purchased from El- Gamhouria Trading for Chemicals and Drugs Company, Egypt.

\section{Color:}

Color values of fresh and dried grape that underwent different pretreatments were measured by a Konica Minolta Colorimeter (CR-300; Minolta, Osaka, Japan). and values, L (lightness/darkness), a (redness/greenness), and $b$ (yellowness/blueness) were measured at 3 different points on the grape. The total color difference $(\Delta \mathrm{E})$ was calculated according to the equation of Oberoi and Sogi (2015).

\section{Total Soluble Solids (T.S.S):}

For the determination of total soluble solids, the fresh grape fruits were homogenized and then centrifuged at 1500 rpm for $10 \mathrm{~min}$. The supernatant was used to measure the soluble solids according to the method described by A.O.A.C., (2012) using a refractometer, Carl Ziess, Jena (Germany) and the results were reported as ${ }^{\circ} \mathrm{Brix}$ at $20^{\circ} \mathrm{C}$.

\section{The Titratable Acidity (TA):}

The titratable acidity (TA) for fresh grape fruits was determined according to the method described by A.O.A.C., (2012) TA was analyzed in triplicate and expressed as citric acid equivalents.

\section{The $\mathrm{pH}$ Value:}

Fresh grape fruit was homogenized and then evaluated as the method described by A.O.A.C., (2012) $\mathrm{pH}$ value determination was carried out by a Jenway $3505 \mathrm{pH}$ Meter (UK) with a combined $\mathrm{pH}$ electrode at $25^{\circ} \mathrm{C}$.

\section{Water Activity:}

The tested samples prepared from dried grape were determined by pouring about $3 \mathrm{~g}$ placed in a sample aw cup. The aw of dried grape, was measured in an AquaLab Model CX-2 meter (Decagon Devices Inc, Pullman, WA) at $25^{\circ} \mathrm{C}$. aw measurements were performed in triplicate (Lewicki and Lukaszu 2000) and (Gabas et al., 2002).

\section{Rehydration Ratio (RR):}

The rehydration_potential of dried grape was evaluated by immersing $5 \mathrm{~g}$ samples in water at $100{ }^{\circ} \mathrm{C}$. Samples were drained and weighed 1, 2, 3, 4, 5, 6, 7, 8, 9 and $10 \mathrm{~min}$ for those at 100 oC. The water absorbed (g) divided by the dry sample weight (g) was expressed as the rehydration ratio. Lin et al., (1998).

\section{Shrinkage (\%):}

Shrinkage is usually expressed by the volume ratio of sample before and after drying. A few researchers have expressed shrinkage as a function of the change of selected dimensions of the samples, measured with vernier or digital callipers Karathanos et al. (1996), (Hatamipour and Mowla, (2003), and Mayor and Sereno, (2004). Mostly, it was expressed in terms of the apparent volume. This volume can be measured by the

$$
\mathbf{S}=\frac{\mathrm{V}_{\mathbf{0}}-\mathbf{V}_{\mathbf{d}}}{\mathbf{V}_{\mathbf{0}}} \times 100 \begin{aligned}
& \text { Archimedes } \\
& \text { principle or by } \\
& \text { a number of } \\
& \text { displacement }
\end{aligned}
$$

techniques.

Where, $\mathrm{S}(\%)$ of shrinkage, $\mathrm{V}_{\mathrm{d}}$ is the apparent volume of the sample after drying, $\mathrm{cm}^{3}$ and $V_{0}$ is the apparent volume of the raw sample, $\mathrm{cm}^{3}$.

\section{Determination of $L$-Ascorbic acid:}

Ascorbic acid content was estimated in fresh and dried fruit and vegetable according 
to AOAC, (2012) using 2, 6 dichlorophenolindophenols by titratable method was expressed as $\mathrm{mg}$ ascorbic acid per $100 \mathrm{~g}$ samples.

\section{Determination of Total Carotenoids:}

The total carotenoid was extracted and determined according to Askar and Treptow, (1993) as follows:

Ten $\mathrm{g}$ from grape were mixed with $30 \mathrm{ml}$ of $85 \%$ acetone in dark and left to stand for $15 \mathrm{~h}$ at room temperature, then filtered through glass wool into a $100 \mathrm{ml}$ volumetric flask and made up to volume with $85 \%$ acetone solution. The absorbance of the acetone extract was measured at 440,644 and $662 \mathrm{~nm}$ against $85 \%$ acetone as a blank using spectrophotometer. The amount of the total carotenoids was calculated according to the following equations:

Chlorophyll $(\mathrm{A})=(9.784 \times \mathrm{E} 662)-(0.99 \times \mathrm{E} 644)$ $\mathrm{mg} /$ liter.

Chlorophyll $(\mathrm{B})=(21.426 \times \mathrm{E} 644)-(4.65 \times \mathrm{E} 662)$ $\mathrm{mg} /$ liter.

Carotenoids $=(4.655 \times$ E440 $)-0.268($ Chl. $(\mathrm{A})+$ Chl.(B) $=\mathrm{mg} /$ liter .

Since:

$\mathrm{E}=$ Absorbance of sample at the indicated wavelength. The results were expressed as $\mathrm{mg} / 100 \mathrm{~g}$ sample.

\section{Total Phenolics:}

The measurement of total phenolics (TPs) content was conducted according to the modified Folin-Ciocalteu method Singleton et al., (1999). Each sample was measured at 760 nm using spectrophotometer (Spekol 11, No. 849101). Gallic acid was used as a standard and results were expressed as gallic acid equivalents (GAE) per $100 \mathrm{~g}$ DM. The linear reading of the standard curve was from 0 to $600 \mu \mathrm{g}$ of gallic acid /milliliter.

\section{Total Flavonoids:}

Total flavonoids were measured according to the method reported by Toor and Savage, (2006). and Zhishen et al., (1999). The samples absorbance was measured at $510 \mathrm{~nm}$ on a spectrophotometer (Spekol11, No. 849101,) against the blank (water) and the total flavonoids were determined from the standard curve. Flavonoid content was expressed as mg Rutin equivalents/ $100 \mathrm{~g}$ DM.

Antioxidant Activity with the 2,2, diphenyl1-picrylhydrazyl Radical Scavenging Method.
The extraction of fruit samples for the determination of antioxidant activity was made according to the same protocol as for total phenolics. The free radical scavenging activity of grape extracts was measured according to the 2,2, diphenyl-1-picrylhydrazyl method reported by Brand-Williams et al., (1995) with some modifications. A methanolic solution $(50 \mu \mathrm{L})$ of the extract was placed in 96-well Microplates, and $200 \mu \mathrm{L}$ of a $0.1 \mathrm{mmol}$ $\mathrm{L}^{-1}$ methanolic solution of DPPH was added and allowed to react in darkness at room temperature. The decrease in absorbance of $\mathrm{DPPH}$ at $520 \mathrm{~nm}$ was measured at $5 \mathrm{~min}$ intervals by a spectrophotometer (MRX Dynex Technologies), until the absorbance stabilized (30 min). Methanol was used as blank solution, and a DPPH solution without test samples served as the control. All sample analyses were performed in triplicate. The DPPH radical scavenging activity of grape methanolic extracts was expressed as milligrams of ascorbic acid equivalents per $100 \mathrm{~g}$.

\section{Organoleptic evaluation:}

Organoleptic evaluation was used to differentiate between the grapes, samples dried by different drying methods under this study. Sensory evaluation was carried out by 10 panels from educational organization members of Food Science and Technology Department, Faculty of Agriculture, Cairo, AlAzhar University. Organoleptic test of dried samples was given to the panelists for quantitative expression of the quality and sensory parameters. The sensory technique was carried out by using a hedonic test tenpoint scale according to Gallali et al., (2000).

\section{Cost analysis:}

Total cost per unit product is evaluated according to El- Awady et al., (1988) based on evaluating fixed and operating costs.

\section{Statistical Analysis:}

Data were subjected to the statistical analysis according to Analysis of Variance (ANOYA) and Duncan's multiple range test (DMRT) of completely randomized design as described by Gomez and Gomez, (1984) Treatment means were compared using the Least Significant Differences (LSD) at 0.05 level of probability and Standard Error. Computations and statistical analysis of data were done using the facilities of computer and statistical analysis system package (1985). 


\section{RESULTS AND DISCUSSION}

Effect of puff drying as compared with the conventional drying on the falling rate period of moisture content of seedless grapes:

The tested samples used in this investigation were seedless grapes. The elapsed time to reach the required moisture content (drying curves) of dried seedless grapes by using the puff drying method as compared with the conventional drying method are listed in Tables (1) and Fig (2). The tested samples were dried at $60^{\circ} \mathrm{C}$ and $1.5 \mathrm{~m} / \mathrm{s}$ air velocity for the conventional drying and the first stage of the puff drying method. From the obtained data, it could be observed that the elapsed drying time to reach the adequate moisture content of seedless grape (17.45) in the final product as recommended by the Egyptian Standard Specifications, (2005). which should not exceed $19 \%$ as that reported in the raisins (dried seedless grape) was $18 \mathrm{~h}$ by using the convention air drying method versus $10 \mathrm{~h}$ by using puff drying method to reach the moisture content $17.50 \%$.

The herein finding indicated that the puff drying system could produce final dried products with the adequate moisture content throughout short time not exceeded than $10 \mathrm{~h}$ for dried seedless grape whereas this require $18 \mathrm{~h}$ by using convection drying system. This too much wide variation of drying time between them mainly related to drying mechanism that applied to puff system. This variation may be due to puff processing may cause quick removal of the moisture content from the product which leads to a faster drying rate. Puff drying technique may be a better alternative way. This method provides a higher drying rate and a better quality of product compared to convection air drying (Candelaria, 1991) because the hot air helps evaporate the surface moisture that is diffused from the inner layer of the dried product. A sudden pressure drop during the puffing (decompression) process of explosion puff drying (EPD) leads to the rapid vaporization of water within the cells of the material, which expands the material accordingly and results in short drying times and high porosity in the product. (Zou et al., 2012 and Yi et al., 2016a).

As illustrated in the obtained data (Fig. 2), it could be indicated that the reduction rate of moisture in the first stage throughout $6 \mathrm{~h}$ of convention air drying was $8.53 \%$ (moisture loss $\% \mathrm{db} / \mathrm{h}$ ) when drying the seedless grape, meanwhile during the second stage of conventional air drying from 6 to $10 \mathrm{~h}$, the reduction rate of moisture decreased gradually to $2.52 \%$. When the reduction rate of moisture decreased throughout the drying process, the explosion puff is used in this stage to reduce the drying time to reach the adequate moisture of the dried samples from $18 \mathrm{~h}$ by using conventional air drying to $10 \mathrm{~h}$ by using the explosion puff. On the other hand, the reduction rate of moisture by using conventional air drying to reach the adequate moisture of the dried samples (from 6 to $18 \mathrm{~h}$ ) was only $1.45 \%$.

From the previous discussion, it could be that the drying rate by using the puff drying method was faster than those for drying rate of convection air drying method at the corresponding drying condition $\left(60^{\circ} \mathrm{C}\right.$ and 1.5 $\mathrm{m} / \mathrm{s}$ air velocity). Where, the falling rate period of seedless grape samples was more 1.80 times when used the puff drying method compared with air convection drying method. The drying rate increased with the decreasing moisture content at the initial stage, and then decreased with the decrease in moisture content. However, the overall drying process mainly took place in the falling rate period (Bi et al., 2015).

\section{Puff drying conditions of the investigated} seedless grape:

After knowing the optimal falling rate period through the drying curve of these tested samples, which beginning of the moisture rate decrease. The tested samples were pre-dried by using the conventional air drying at $60^{\circ} \mathrm{C}$ and $1.5 \mathrm{~m} / \mathrm{s}$ air velocity for $6 \mathrm{~h}$ to reach the moisture content 34.85 . The predried samples were puffed at $80^{\circ} \mathrm{C}$ with used the different pressure $0.10,0.15$ and $0.20 \mathrm{MPa}$ at different dwell times (5,10 and $15 \mathrm{~min}$.), and then all tested samples were dried in vacuum drying (at $60^{\circ} \mathrm{C}$ under vacuum $0.10 \mathrm{MPa}$ ) to reach the adequate moisture content. The effect of puffing conditions such as different pressure and dwell time at $80^{\circ} \mathrm{C}$ to reach the optimal conditions for drying the tested samples with the best the rehydration time (min.) are shown in Table 2.

From the obtained data in Table 2, it could be exhibited that the best explosion puff of predried seedless grape was observed when used $0.20 \mathrm{MPa}$ pressure with $10 \mathrm{~min}$. of the dwell time at $80^{\circ} \mathrm{C}$ which having the optimal rehydration time $(7 \mathrm{~min}$.) compared to the other treatments. Likewise, the same rehydration time (7 $\mathrm{min}$.) was also observed at the same conditions $\left(0.20 \mathrm{MPa}\right.$ at $\left.80^{\circ} \mathrm{C}\right)$, but with the highest dwell time (15 min.). On the 
other hand, the other treatments were recorded rehydration time more than $7 \mathrm{~min}$.

In this case, why the rehydration time circumscribes the optimal drying conditions, because its evaluation index of the damage to the product caused by dehydration and can indicate the physical and chemical changes in the structure and composition of plant tissue caused by drying and treatments (Krokida and Maroulis 2001). In case of puff drying, the amount of moisture absorbed by the tested samples increases with rehydration time, but at a decreasing rate up to saturation level. The rehydration stabilized under optimal conditions for puff drying.

\section{Optimal puff drying conditions of seedless grape:}

From the obtained data (table 3 ) it could be observed that seedless grape samples were subjected to dry in $60^{\circ} \mathrm{C}$ in conventional air drying for $6 \mathrm{~h}$ firstly, then dried by explosion puffing drying at puffing temperature $80^{\circ} \mathrm{C}$ for dwell time $10 \mathrm{~min}$, finally the vacuum drying temperature $60^{\circ} \mathrm{C}$ for $230 \mathrm{~min}$. Compared with the conventional air drying, conventional airexposure puffing combination drying technology improves the quality of dried seedless grape and shorten the drying time ( $\mathrm{Li}$ et al, .2016). Explosion puff drying (EPD) usually involves a pre-drying step prior to puffing; a partially dried layer is formed on the surface of material that is crucial for achieving puffing (Varnalis et al., 2001). The present results are in accordance with the data obtained by Tabtaing et al. (2017) and Song et al. (2018).

\section{The Effect of the puff drying method on the antioxidant compounds of seedless grape as compared with the conventional air drying:}

The effect of experimental drying methods on antioxidant compounds such as $L$-ascorbic acid, total carotenoids, total phenolic and flavonoids compounds of testing seedless grape fruit are presented in Table (4).

As given in the obtained results (Table 4), it could be mentioned that all tested antioxidants (L-ascorbic acid, total carotenoids, total phenolic and flavonoids compounds) were significantly reduced by all drying methods used, when compared to their original level in fresh seedless grape sample. The present results are relatively with those found by Carranza-Concha et al., (2012) and Yi et al., (2016a).

Concerning the effect of conventional air drying as compared with puff drying methods on $L$-ascorbic acid of dried seedless grapes as shown in the obtained data in Table (5), no significant difference in loss of $L$-ascorbic acid was observed after drying processes for two different drying methods in the dried seedless grape samples, whereas the retention (\%) of $L$ ascorbic acid in PD- dried seedless grape was nearly $(53.33 \%)$ to that found in the AD-dried seedless grape $(53.13 \%)$. The results obtained are relatively with the data obtained by Yi et al., (2016a).

As illustrated in the same Table, it could be revealed that the highest loss of the total carotenoids $(41.88 \%)$ was observed in dried seedless grapes by AD, which was higher than the corresponding loss of the total carotenoids of dried seedless grapes by PD drying method, which was recorded only 26.28. Moreover, significant difference was observed in the total carotenoids between the samples dried by the $\mathrm{AD}$ and the samples dried by using PD, whereas the PD drying method caused more retention of the total carotenoids (73.72 $\mathrm{mg} / 100 \mathrm{~g}$ on dry weight basis) than those obtained by AD drying method $(66.57 \mathrm{mg} / 100 \mathrm{~g}$ on dry weight basis). A higher obvious retention of the total carotenoids in dried seedless grapes by using PD compared to the $\mathrm{AD}$ drying method may be due to the short drying time requiring ( $10 \mathrm{~h}$ for PD drying compared to $18 \mathrm{~h}$ for $\mathrm{AD}$ drying methods). (Abiodun and Akinoso, 2014).

With regard the total phenolic compounds as given in the same Table, there is a considerable significant alteration of the content of total phenolic compounds was noticed between the PD-dried seedless grapes (276.73 mg/100g on dry weight basis) and ADdried seedless grapes $(224.35 \mathrm{mg} / 100 \mathrm{~g}$ on dry weight basis). Where, the retention of the phenolic compounds recorded $71.85 \%$ for the PD-dried seedless grapes versus to $58.25 \%$ for the AD-dried seedless grapes. The heat and pressure during puffing also cause a change in the chemical composition of puffed materials. For example, it has been reported that the explosion-puffing significantly increased in the total polyphenol content of jujubes, which led to a corresponding increase in antioxidant properties (Du et al., 2013). These results are coincident with the data observed by TéllezPérez et al., (2013); Yi et al., (2016a) and Chiang et al., (2017).

As shown in Table (4), it could be demonstrated that the dried seedless grapes by using PD method had the highest amount of total flavonoids $(84.85 \mathrm{mg} / 100 \mathrm{~g} \mathrm{DM})$ than those found in dried seedless grape by using 
AD method (63.26 mg/100g DM). Whereas, the retention percentage of the flavonoids compounds was $63.55 \%$ in the PD-dried seedless grapes versus to $47.38 \%$ in the ADdried seedless grapes. This observation is similar to that mentioned by Téllez-Pérez et al., (2013); Yi et al., (2016a) and Chiang et al., (2017).

From the previous discussion, it could be concluded that the puff drying system has a great positive effect on protective antioxidant components (L-ascorbic acid, carotenoids, phenolics and flavonoids in the seedless grapes and mostly retained in the final dried products, which mostly lost when the AD drying system used. This was obviously shown in dried seedless grapes produced by puff drying systems than that obtained by using the conventional air drying systems.

The effect of puff drying (PD) method on the physico-chemical properties of seedless grape as compared with the conventional air drying (AD).

The physico-chemical properties of dried seedless grape by using puff drying (PD) method as compared to the convention drying method (AD) such as $\mathrm{pH}$ value, total acidity (as a citric acid \%), total soluble solid (TSS\%), water activity (aw) volumetric shrinkage (\%), rehydration ratio, color index (measuring by Hunter Lab) and texture profile (using texture analyzer) are listed in Tables (5, 6 and 7).

As given in the obtained results in Table (5), it could be mentioned that slight increase in $\mathrm{pH}$ value in the dried seedless grape by using both $\mathrm{AD}$ and $\mathrm{PD}$ methods when compared with seedless grape fresh (3.49). Also, no significant difference was observed in the total acidity (as a citric acid \%) between the tested sample dried by $\mathrm{AD}(1.73 \%)$ and the same sample dried by PD (1.77\%).

In the same trend, no significant difference was observed in TSS (\%) between the tested samples dried by two drying methods.

As regard to the volumetric shrinkage (\%) as shown in Table (5), the tested sample dried by $\mathrm{AD}$ was recorded drastically higher percent of volumetric shrinkage $(40.11 \%)$ when compared with the dried sample by PD which recorded only $3.24 \%$, whereas it was more than 12.37 times in the sample dried by $\mathrm{AD}$ as compared with than that found in sample dried by PD. Shrinking is an important aspect which should be taken into consideration while developing a model for describing drying of foodstuffs. Shrinkage during dehydration of fruits and vegetables occurs when the viscoelastic matrix contracts into the space previously occupied by the water removed from the cells (Aguilera, 2003). Shrinkage modifies the shape and dimension of products and is directly related to the loss of water during drying, which in turn affects the mass transport phenomena and case hardening that occurs in some drying processes (Aguilera and Stanley, 1999).

As illustrated in the same Table, it could be noticed that the water activity (aw) was recorded 0.623 in the tested sample dried by $\mathrm{AD}$, which was more than that obtained by the dried sample by PD (0.582).

From the same data as shown in Table (5), it could be revealed that the puff dried sample was presented the highest rehydration ratio (3.58) than those recorded by the conventional air dried sample (2.63), where obvious significant difference was noticed in rehydration ratio between the dried samples by $\mathrm{AD}$ and $\mathrm{PD}$. The higher rehydration ratio in puff dried seedless grape can be explained that less physical and chemical changes occurred by the convection air drying process due to shorter drying time and uniform heating. Because some irreversible physicochemical changes occur during drying and the solutes leaking from damaged cells migrate to the surface to form a crust resulting in a relatively closed surface structure (Cui et al., 2003). It can also be seen that puff drying samples showed the highest rehydration ability because of the porous structure compared with convectional air drying samples. The present results are in agreement with the data obtained by Krokida and Maroulis, (2001); Burin et al., (2010) and Panceri et al., (2013).

From the previous discussion, it could be concluded that the puff drying system caused a higher rehydration ratio and obviously lower volumetric shrinkage (\%) in the tested samples than that obtained when used the conventional air drying methods. These results confirmed that the puff drying system, leading to improve the quality criteria of the dried product such as rehydration ratio, which it widely used as a quality evaluation method after drying. Rehydration rate is widely considered as a quality evaluation index of the damage to the product caused by dehydration and can indicate the physical and chemical changes in the structure and composition of plant tissue caused by drying and treatments. Rehydration ratio showed high water absorption rate at the beginning of the process because the pores in the dried grape were 
empty and, as water started to fill the pores, the absorption rate decreased. It can also be seen that puff drying samples showed the highest rehydration ability because of the porous structure compared with convection air drying samples.

The effect of puff drying method on the color index of seedless grape as compared with the conventional air drying are presented in Table (6).

From the obtained data, it could be observed that the puff dried seedless grape was obvious higher in $L$ and $b$ values when compared with the conventional air dried seedless grape, which was recorded 48.88 and 15.01 versus to 33.53 and 4.01 for the conventional air dried seedless grape. Also, a value was found in the conventional air-dried seedless grape (7.40) slighter than that found in the puff dried seedless grape (6.30). The decrease in the $L$ value with increasing $a$ value in the tested sample indicated the increase in the browning color as the reported by Deng and Zhao (2008) which explain the change in the color during the drying process. They reported that a decrease in $L^{*}$ and an increase in $a^{*}$ indicated an increase in browning discoloration, which was related to the Maillard reaction (nonenzymatic browning reaction), caramelization and pigment degradation (Tabtiang et al., 2012 and Wang et al., 2010).

Also, from the same results, it could be exhibited that a considerable significant variation was noticed in $L$ and $b$ values among the puff dried sample and the convention dried sample.

As given in the data obtained in Table (6), it could be also noticed that significant differences in color index among the puff dried seedless grape samples and the convention dried sample, whereas the total color difference in seedless grape samples dried by AD was (50.93) more than those found in the seedless grape samples dried by PD (24.60). Puffing process presented lower $\Delta E$ values, indicating fewer color differences to the fresh seedless grape. Because of the fast moisture removal, and the shorter processing time, puff dried samples presented few color changes than the conventional air drying process. The present results are in accordance with the data obtained by Saxena et al. (2012) and Zhou et al. (2017).

The overall color changes of the dried seedless grape samples can be observed from its $\Delta E$ value. PD dried seedless grape showed a lower value of $\Delta E$ than the AD dried seedless grape, suggesting that the puff drying finish products obtained a color that was more similar to the fresh seedless grape, possibly by minimizing color deterioration during predrying stage (Yi et al., 2016b). The color of the dried seedless grape samples by using the puff drying method as compared with the conventional air drying method is shown in Fig. (3).

From the obtained data in Table (7), it could be shown that the hardness in AD-dried seedless grape recorded approximately more than two times when compared the hardness in PD-dried seedless grape, whereas it was recorded $62.55(\mathrm{~N})$ of $\mathrm{AD}$-dried seedless grape versus to $34.03(\mathrm{~N})$ for $\mathrm{PD}$-dried seedless grape.

From the same Table, the PD-dried seedless grape recorded, the better adhesiveness and resilience than that presented in $\mathrm{AD}$-dried seedless grape. The lowest adhesiveness was observed in the PD-dried seedless grape $(0.40$ $\mathrm{mJ})$, while the AD-dried seedless grape showed the highest Adhesiveness $(0.80 \mathrm{~mJ})$. The decreased or low adhesiveness is an important property of dehydrated fruit which maintains the shelf life of dried fruit (Vijaykumar and Naik, 2018).

The effect of puff drying method on the antioxidant activity of seedless grape as compared with the conventional air drying:

The antioxidant capacity and scavenger activity of fresh and the dried seedless grapes by using puff drying and the conventional airdrying methods are shown in Table (8).

From the obtained data, it could be observed that the antioxidant activity of fresh seedless grapes was $(84.43 \%)$ inhibition of $\mathrm{DPPH}$ free radicals. As illustrated in the same Table (8), it could be noticed that significant difference was observed in scavenging capacity against DPPH of the seedless grape samples dried by $\mathrm{PD}$ and the same samples dried by AD. Where, the inhibition of DPPH free radicals of PD- seedless grape was recorded $65.69 \%$ compared to $63.02 \%$ for ADseedless grape.

These results may be attributed to the antioxidant compounds found at a higher content in the samples dried by PD drying method more than that found in the samples dried by $\mathrm{AD}$ as previously discussed in the table (8). These results are in agreement with the data obtained by Du et al., (2013) which they found that an explosion-puffed jujube 
was significantly higher than that found in sun-dried counterparts. Also, the present results are relatively with the data obtained by Du et al., (2013) and Han et al., (2017).

Effect of puff drying (PD) compared to the convection air drying (AD) on the organoleptic quality properties of producing dried seedless grapes.

The organoleptic properties of dried seedless grape samples were generally the final guide of the quality from the consumer's point of view. Thus, it was beneficial to make a comparative evaluation sensorial for the dried seedless grapes by using the puff drying method as compared to the conventional air drying methods. All dried samples were evaluated sensorial by the ten panelists for mentioned attributes according to given scores and the mean values of scores were statistically analyzed $(p<0.05)$. The statistically obtained results are recorded in Table (9).

From sensory evaluation results in Table (9), it could be observed that there is a significant alteration in color property, which is considered one of the most important of the organoleptic quality properties of dried products, between the seedless grape samples dried by PD (8.50) and the samples dried by using AD (7.08). These results may be due to the much longer drying time by using AD $18 \mathrm{~h}$ when compared with the puff drying method, which recorded $10 \mathrm{~h}$ drying time, which may cause a significant diminution in color property between the samples dried by $\mathrm{AD}$ and the PD drying methods.

From the statistical analysis for taste and odor properties as shown in Table (9), it could be indicated that there are no significant differences $(P>0.05)$ was observed between the seedless grapes dried by $\mathrm{PD}$ and the corresponding samples dried by $\mathrm{AD}$, whereas PD-dried samples were represented 8.47 and 8.00 compared to 8.17 and 7.83 of AD-dried samples for the taste and odor properties; respectively.

Also, from sensory evaluation results in Table (9), it could be noticed that there is a significant alteration in texture properties between the seedless grapes samples dried by PD and the samples dried by using AD. Where, the highest score of a texture property (8.83) was observed in the seedless grapes dried by PD, while the score of a texture property of seedless grapes dried by $\mathrm{AD}$ was 7.83. These results may be due to the puff drying process, an abrupt transition from high pressure to a vacuum led to the expansion of products and the formation of porous structure, thus resulting in products with high crispness (Yi et al., 2016a). However, severe shrinkage of products was usually observed with a long-time exposure of conventional air drying, thus leading to the significant increase of product hardness.

Concerning the overall acceptability of seedless grapes dried by using AD compared with the corresponding samples dried by PD, as illustrated in Table (9), it could be indicated that the highest sensory judging score of overall acceptability was found in PD-dried samples (8.83) versus to 8.17 of $\mathrm{AD}$-seedless grape samples.

Finally, it could be shown that the seedless grapes samples dried by using PD exhibited good sensory properties and better acceptability such as color, texture and overall acceptability when compared with the corresponding samples dried by AD. These results may be due to the short drying time and the obvious porosity in the dried sample structure which formed by suddenly pressure used in the puff drying method as compared with the convention drying methods (AD) lead to enhancement in the quality criteria of the final products by Guiné et al., (2015) and Lokhande et al., (2017).

The economic evaluation of puff drying compared to convection air drying for dried seedless grapes:

In the present study the cost per LE/ $/ \mathrm{kg}$ of dried product for grape for different drying systems namely, air convection drying (AD) and puff drying (PD) are shown in Table (10). The production cost was used in present work for identifying the economic evaluation of aid convection air drying compared to puff drying method utilized for producing dried grape.

With regards to the production cost of one kilogram for dried tested products, the puff drying system had much lower up to 1.79 times of grape than that obtained by convection air drying system. This highly affected by fixed and operating costs that directly affected by the drying time. Because the drying time of PD dryer is more less than that required for air convection drying method, therefore, the power and operating costs are too much decrease and this interpret the lower values of producing one $\mathrm{Kg}$ of grape by using PD dryer than that occurred by air convection drying.

The cost of drying by convection air system per year is 7339.8, while the puff drying is 
7372.58 these results are in agreement with the data obtained by Kozempel et al., (1989). They found that the process costs are similar to the cost of conventional convection air drying.

In addition, the calculated production costs of one kilogram of all dried products by using convection air dryer (AD) was found a much higher than that obtained by the puff dryer system. It is also clear that the divergence between the production costs of different dried products for the same drying method may be due to the physical, chemical, and size reduction pretreatment (whole or cubes) and can be related to the difference of moisture migration mechanism that directly proportional to drying time.

Finally, the puff dryer system, leading to sharply reduce the drying time, and thus lead to a reduction cost of the dried products. Have better drying performance, but the capital and maintenance costs for such dryers are significantly higher. So new trends in food processing focus on the marriage of new and innovative techniques to the Traditional Hot air Drying (THD) with the objective of drying intensifying resulting in costs reduction (short drying time with low energy consumption), and product's quality preservation

The obtained results show that the puff drying (PD) can be used as an alternative technique to dry the foodstuffs with high quality during the short time decreasing the costs of the operation Albitar et al., (2011) and Téllez-Pérez et al., (2013). In general, PDrelated drying can meet the four major requirements in drying of foods: speed of operation, energy efficiency, cost of operation, and quality of dried products (Gunasekaran, 1999). The increased demand for plant-origin foods in the fast-dehydrated form has increased interest in PD dehydration (Zhang and $\mathrm{Xu}, 2003)$. Not only shorter drying time and shorter rehydration time can be achieved by explosive puffing, but other favorable effects are discovered by researchers. These commodities have longer frozen storage life, excellent flavor and color, ambient temperature storage possibility, and durability while only need minimal storage and transportation costs (Yuting, 2013).

\section{CONCLUSION}

Puff drying is a process by which lower drying time could be accomplished that directly reflected on dried seedless grapes as excellent levels of average drying efficiency, high quality of physical characteristics, great positive effect on protecting the biochemical components and sensorial quality properties.

\section{REFERENCES}

A.O.A.C., 2012. Official Methods of Analysis of the Association of Official Analytical Chemists International (19th ed). Gaithersburg, MD, USA.

Abiodun, O.A., Akinoso, R., 2014. Effect of Delayed harvesting and pretreatment methods on the antinutritional contents of trifoliate yam flour. Food Chem., 146, 515-520.

Aguilera, J.M., Stanley, D.W., 1999. Microstructural Principles of Food Processing and Engineering, 2nd Ed., Gaithersburg, Aspen Publishers.

Aguilera, J.M., 2003. Drying and dried products under the microscope. Food Sci. Technol. Int., 9 (3), 137-143.

Albitar, N., Mounir, S., Besombes, C., Allaf, K., 2011. Improving the drying of onion using the instant controlled pressure drop technology. Drying Technol., 29 (9), 993-1001.

Askar, A., Treptow, H., 1993. Amines. Encyclopedia of food science, Food Technol. Nutr., 141-146.

Bi, J.F., Wang, X., Chen, Q.Q., Liu, X., Wu, X.Y., Wang, Q., Lv, J., Yang, A.J., 2015. Evaluation Indicators of explosion puffing Fuji apple chips quality from different Chinese origins. LWT - Food Sci. Technol. 60, 1129-1135.

Brand-Williams, W., Cuvelier, M.E., Berset, C., 1995. Use of a free radical method to evaluate antioxidant activity. Food Sci. Technol., 28 (1), 25-30.

Burin, V.M., Falcão, L.D., Gonzaga, L.V., Fett, R., Rosier, J.P., Bordignon-Luiz, M.T., 2010. Colour, phenolic content and antioxidant activity of grape juice. Food Sci. Technol., 30 (4), 1027-1032.

Candelaria, N.M., 1991. Dehydration of vacuum-puffed fruits and vegetables. University Library, University of the Philippines at Los Banos. http://agris.fao.org/agrissearch/search.do?recordID=PH9111186.

Carranza-Concha, J., BenUoch, M., Camacho, M. M., Martinez-Navarrete, N., 2012. Effects of drying and pretreatment on the nutritional and functional quality of raisins. Food Bioprod. Process., 90, 243-248.

Chiang, P.S., Lee, D.J., Whiteley, C.G., Huang, C.Y., 2017. Extracting antioxidant phenolic compounds from compressional-puffing pretreated Pinus morrisonicola: Effects of operational parameters, kinetics and characterization. J. Taiwan Inst. Chem. Eng., 75, 70-76.

Cui, Z., Xu, S., Sun, D., 2003. Dehydration of garlic slices by combined microwave-vacuum and air drying. Drying Technol., 21 (7), 1173-1184.

Deng, Y., Zhao, Y., 2008. Effect of pulsed vacuum and ultrasound osmopretreatments on glass transition temperature, texture, microstructure and calcium penetration of dried apples (Fuji). LWT - Food Sci. Technol., 41 (9), 1575-1585.

Du, L.J., Gao, Q.H., Ji, X.L., Ma, Y.J., Xu, F.Y., Wang, M., 2013. Comparison of flavonoids, phenolic acids, and 
antioxidant activity of explosion-puffed and sundried jujubes (Ziziphus jujuba Mill.). J. Agric. Food Chem., 61 (48), 11840-11847.

El-Awady, M.N., Mosutafa., A.M., El-Gindy, A.M., Genaidy, M.A., 1988. A trial on solar energy drying for agricultural products with simple setup. Misr J. Agric. Eng., 5 (3), 377-392.

El-kassas, F.B., Ali, A.M., Mostafa, S.E., 2014. Phenolic compounds as antioxidants of some products manufactured from two cultivated Egyptian varieties of seedless grapes. Ann. Agric. Sci., 59 (2), 195-199.

ESS., Egyptian Standard Specifications, No. 285/2005, Dried grapes (raisins).

Gabas, A.L., Menegalli, F.C., Ferrari, F., Talis-Romero, J., 2002. Influence of drying conditions on the rheological properties of prunes. Dry. Technol., 20 (7), 1485-1502.

Gallali, Y.M., Abujnah, Y.S., Bannani, F.K., 2000. Preservation of fruits and vegetables using solar dryer: A comparative study of natural and solar drying, Ш, chemical analysis and sensory evaluation data of the dried samples (grapes, figs, tomatoes and onions). Renew. Energ., 19 (1-2), 203-212.

Gomez, K.A., Gomez, A.A., 1984. Statistical Procedures for Agricultural Research, 2nd Ed., John Wiley, NY, USA.

Guiné, R.P., Almeida, I.C., Correia, A.C., Gonçalves, F.J., 2015. Evaluation of the physical, chemical and sensory properties of raisins produced from grapes of the cultivar Crimson. J. Food Meas Charact., 9 (3), 337-346.

Gunasekaran, S. 1999. Pulsed microwave-vacuum drying of food materials. Dry. Technol., 17 (3), 395-412.

Han, S.H., Ko, B.S., Ahn, S.H., Noh, D.O., Suh, H. J., 2017. Comparison of the antioxidant activities of roasted and explosive puffed coffees. Int. J. Food Sci. Technol., 52 (6), 1417-1424.

Hatamipour, M.S., Mowla, D., 2003. Correlations for shrinkage, density and diffusivity for drying of maize and green peas in a fluidized bed with energy carrier. J. Food Eng., 59, 221 -227.

Karathanos, V.T., Kanellopoulos, N.K., Belessiotis., V.G., 1996. Development of porous structure during air drying of agriculture plant products. J. Food Eng., 29, 167-183.

Kassem, A.S., Shokr, A.Z., El-Mahdy, A.R., Aboukarima, A.M., Hamed, E.Y., 2011. Comparison of drying characteristics of Thompson seedless grapes using combined microwave oven and hot air drying. J. Saudi Soc. Agric. Sci., 10 (1), 33-40.

Kozempel, M.F., Sullivan, J.F., Craig, J.C., Konstance, R.P., 1989. Explosion puffing of fruits and vegetables. J. Food Sci., 54 (3), 772-773.

Krokida, M.K., Maroulis, Z.B., 2001. Structural properties of dehydrated products during rehydration. Int. J. Food Sci. Technol., 36 (5), 529-538.

Lewicki, P.P., Lukaszu k,A., 2000. Changes of rheological properties of apple tissue undergoing convective drying. Dry. Techno., 18 (3), 707-722.
Lin, T.M., Durance, T.D., Scaman, C.H. 1998. Characterization of vacuum microwave, air- and freeze-dried carrot slices. Food Res Int., 31 (2), 111117.

Liu, L., Wang, Y., Fan, D., Mi, Y., 2015. Using phenolphthalein as a promising indicator to monitor the vacuum freezedrying process. Mater. Lett., 139, 245-248.

Lokhande, S.M., Ranveer, R.C., Sahoo, A.K., 2017. Effect of microwave drying on textural and sensorial properties of grape raisins. Int. J. Chemtech Res., 10 (5), 938-947.

Mayor, L., Sereno, A.M., 2004. Modelling shrinkage during convective drying of food materials: a review. J. Food Eng., 61 (3), 373-386.

Oberoi, D.P.S., Sogi, D.S., 2015. Drying kinetics, moisture diffusivity and lycopene retention of watermelon pomace in different dryers. J. Food Sci. Technol., 52 (11), 7377-7384. .

Panceri, C.P., Gomes, T.M., De Gois, J.S., Borges, D.L., Bordignon-Luiz, M.T., 2013. Effect of dehydration process on mineral content, phenolic compounds and antioxidant activity of Cabernet Sauvignon and Merlot grapes. Food Res. Int., 54 (2), 1343-1350.

SAS., 1985. Statistical Analysis System (SAS) user's guide: Statistics, 5 Ed. SAS Institute, Cary, N.C.,

Saxena, A., Maity, T., Raju, P.S., Bawa, A.S., 2012. Degradation kinetics of colour and total carotenoids in jackfruit (Artocarpus heterophyllus) bulb slices during hot air drying. Food Bioproc. Technol., 5 (2), 672-679.

Singh, R.P., Heldman, D.R., 2009. Introduction to food engineering. Gulf Professional Publishing. Academic Press, Elsevier, California, 1-864.

Singleton, V.L., Orthofer R., Lamuela-Raventos, R.M., 1999. Analysis of total phenols and other oxidation substrates and antioxidants by means of folinciocalteu reagent. Method. Enzymol., 299, 152-178.

Song, J., Gonzalles, G., Liu, J., Dai, Z., Li, D., Liu, C., Zhang, M., 2018. Optimization of explosion puffing drying for high-value yellow-fleshed peach crisps using response surface methodology. Dry. Technol., 37 (8), 929-940.

Soysal, Y., Oztekin, S., 2001. pH-postharvest technology: comparison of seven equilibrium moisture content equations for some medicinal and aromatic plants. J Agric Eng. Res., 78, 57-63.

Tabtaing, S., Paengkanya, S., Tanthong, P., 2017. Effects of chemical composite, puffing temperature and intermediate moisture content on physical properties of potato and apple slices. In J. Phys. Conf. Ser., 901, 012035.

Tabtiang, S., Prachayawarakon, S., Soponronnarit, S., 2012. Effects of osmotic treatment and superheated steam puffing temperature on drying characteristics and texture properties of banana slices. Dry. Technol., 30 (1), 20-28.

Téllez-Pérez, C., Cardador-Martínez, A., Mounir, S., Montejano-Gaitán, J.G., Sobolik, V., Allaf, K. 2013. 
Effect of instant controlled pressure drop process coupled to drying and freezing on antioxidant activity of green" Poblano" pepper (Capsicum annuum L.). Food Nutr. Sci., 4 (3), 321-334.

Toor, R.K., Savage, G.P., 2006. Effect of semi-drying on the antioxidant components of tomatoes. Food Chem., 94, 90-97.

Varnalis, A.I., Brennan, J.G., MacDougall, D.B., 2001. A proposed mechanism of high-temperature puffing of potato. Part I. The influence of blanching and drying conditions on the volume of puffed cubes. J. Food Eng., 48 (4), 361-367.

Vijaykumar, A., Naik V., 2018. Texture profile analysis of Sonaka and Thompson seedless raisins. J. Postharvest Technol., 6 (4), 75-81.

Viswanathanl, R., Jayas, D.S., Hulasare, R.B. 2003. Sorption Isotherms of Tomato Slices and Onion Shreds. Biosys. Eng., 86 (4), 465-472.

Wang, H., Zhang, M., Mujumdar, A.S., 2014. Comparison of three new frying methods for drying characteristics and quality of shiitake mushroom (Lentinus edodes). Dry. Technol., 32 (15), 1791-1802.

Wang, J., Wang, J.S., Yu, Y., 2007. Microwave drying characteristics and dried quality of pumpkin. Int. J. Food Sci. Technol., 42 (2), 148-156.

Wang, R., Zhang, M., Mujumdar, A.S., 2010. Effect of osmotic dehydration on microwave freeze-drying characteristics and quality of potato chips. Dry. Technol., 28 (6), 798-806.

Yi, J., Wang, P., Bi, J., Liu, X., Wu, X., Zhong, Y., 2016 a. Developing novel combination drying method for jackfruit bulb chips: Instant controlled pressure drop (DIC)-assisted freeze drying. Food Bioproc. Technol., 9 (3), 452-462.
Yi, J., Zhou, L., Bi, J., Chen, Q., Liu, X., Wu, X., 2016 b. Impacts of pre-drying methods on physicochemical characteristics, color, texture, volume ratio, microstructure and rehydration of explosion puffing dried pear chips. J. Food Process. Pres., 40 (5), 863873.

Yuting, W., 2013. Energy-efficient industrial dryers of berries. http://www.divaportal.org/smash/record.jsf?pid=diva2\%3A630120\&ds wid $=471$

Zhang, M., Xu, Y.Y., 2003. Research developments of combination drying technology for fruits and vegetables at home and abroad. J. Wuxi Univ. Light Indust., 22 (6), 103-106.

Zhang, M., Tang, J., Mujumdar, A.S., Wang, S., 2006. Trends in microwave-related drying of fruits and vegetables. Trends Food Sci Technol., 17, 524-534.

Zhishen, J., Mengcheng, T., Jianming, W., 1999. The determination of flavonoid contents in mulberry and their scavenging effects on superoxide radicals. Food Chem., 64, 555-559.

Zhou, L., Guo, X., Bi, J., Yi, J., Chen, Q., Wu, X., Zhou, M., 2017. Drying of garlic slices (Allium sativum L.) and its effect on thiosulfinates, total phenolic compounds and antioxidant activity during infrared drying. J. Food Process Pres., 41 (1), 712-734.

Zou, K., Teng, J., Huang, L., Dai, X., Wei, B., 2012. Effect of osmotic pretreatment on quality of mango chips by explosion puffing drying. LWT - Food Sci. Technol., 51, 253-259.

Zou, K., Teng, J., Huang, L., Dai, X., Wei, B., 2013. Effect of osmotic pretreatment on quality of mango chips by explosion puffing drying. LWT - Food Sci. Technol., 51, 253-259. 
Table 1. Effect of puff drying method as compared to convection air drying on the falling rate period of moisture content (\%) for producing dried seedless grape.

\begin{tabular}{ccc}
\hline \multirow{2}{*}{ Drying time (h) } & \multicolumn{2}{c}{ Moisture content dry basis (\%) } \\
\cline { 2 - 3 } & Air Drying & Puff Drying \\
\hline $\mathbf{0}$ & 86.00 & 86.00 \\
$\mathbf{4}$ & 67.85 & 67.85 \\
$\mathbf{6}$ & 55.30 & 55.30 \\
$\mathbf{8}$ & 34.85 & 34.85 \\
$\mathbf{1 0}$ & 29.90 & 29.35 \\
$\mathbf{1 2}$ & 24.79 & 17.50 \\
$\mathbf{1 4}$ & 21.31 & ---- \\
$\mathbf{1 6}$ & 19.52 & --- \\
$\mathbf{1 8}$ & 18.85 & --- \\
\hline
\end{tabular}

End of the drying process

Table 2. Optimal conditions for dried seedless grape by puff drying

\begin{tabular}{ccccc}
\hline $\begin{array}{c}\text { *Puffing } \\
\text { Moisture } \\
(\%)\end{array}$ & $\begin{array}{c}\text { Pressure } \\
(\mathbf{M p a})\end{array}$ & $\begin{array}{c}\text { Temperature } \\
\left({ }^{\circ} \mathbf{C}\right)\end{array}$ & $\begin{array}{c}\text { Dwell time } \\
\text { (Min.) }\end{array}$ & $\begin{array}{c}\text { Rehydration time } \\
\text { (Min.) }\end{array}$ \\
\hline & 0.10 & & 5 & 10 \\
& 0.15 & & 5 & 9 \\
34.85 & 0.20 & & 5 & 9 \\
& 0.10 & 80 & 10 & 8 \\
& 0.15 & & 10 & $7^{*}$ \\
& $0.20^{*}$ & & 15 & 8 \\
& 0.10 & & 15 & 7 \\
\hline
\end{tabular}

Puffing Moisture (\%): the moisture content in dried seedless grape after pre-drying for $6 \mathrm{~h}$ in conventional drying oven.

Table 3. Optimal puff drying conditions of seedless grape

\begin{tabular}{lc}
\hline Puffing conditions & Seedless grape \\
\hline Pre-drying time (h) & 6.00 \\
Puffing Moisture (\%) & 34.85 \\
Pressure (Mpa) & 0.20 \\
Temperature $\left({ }^{\circ} \mathrm{C}\right)$ & 80.00 \\
Dwell time (min.) & 10.00 \\
Vacuum drying time (min.) & 230.00 \\
Rehydration time (min.) & 7.00 \\
Combination of Pre-drying+puff+vacuum $(\mathbf{h})$ & 10.00 \\
\hline
\end{tabular}

Table 4. The effect of experimental drying methods on the antioxidant compounds of seedless grape as compared with the conventional air drying (Means \pm SE) on dry weight basis

\begin{tabular}{llllllll}
\hline $\begin{array}{l}\text { Antioxidant } \\
\text { compounds (mg/100g } \\
\text { DM) }\end{array}$ & Fresh & Air drying & $\begin{array}{l}\text { Retention } \\
\text { (\%) }\end{array}$ & Puff drying & $\begin{array}{l}\text { Retention } \\
\text { (\%) }\end{array}$ & LSD \\
\hline $\begin{array}{l}\text { L-ascorbic } \\
\text { content }\end{array}$ & acid & 24.32 & $12.92^{\mathrm{a}} \pm 0.288$ & 53.13 & $12.97^{\mathrm{a}} \pm 0.173$ & 53.33 & 0.934 \\
$\begin{array}{l}\text { Total Carotenoids } \\
\text { Total phenolic }\end{array}$ & 114.54 & $66.57^{\mathrm{b}} \pm 0.288$ & 58.12 & $84.44^{\mathrm{a}} \pm 0.259$ & 73.72 & 1.078 \\
$\begin{array}{l}\text { content } \\
\text { Total flavonoids }\end{array}$ & 385.15 & $224.35^{\mathrm{b}} \pm 1.154$ & 58.25 & $276.73^{\mathrm{a}} \pm 0.028$ & 71.85 & 3.207 \\
\hline
\end{tabular}

Data are expressed as mean \pm SE. The values given represent means of three determinations. Means in the same column with different letters are significantly $(P \leq 0.05)$ different. LSD: least different significantly at $(P \leq 0.05)$ according to Duncan's multiple range test. 
Table 5. Effect of puff drying method on physico-chemical properties of seedless grape as compared with the conventional air drying (Means \pm SE).

\begin{tabular}{ccccc}
\hline $\begin{array}{c}\text { Physicochemical } \\
\text { properties }\end{array}$ & \multicolumn{3}{c}{ Drying methods } & \multirow{2}{*}{ LSD } \\
\cline { 2 - 4 } & Fresh & Conventional air drying & Puff drying & 0.122 \\
pH value & 3.49 & $3.62^{\mathrm{a}} \pm 0.017$ & $3.57^{\mathrm{a}} \pm 0.040$ & 0.035 \\
T.A.\% (as citric acid) & 0.96 & $1.73^{\mathrm{a}} \pm 0.005$ & $1.77^{\mathrm{a}} \pm 0.01$ & 0.906 \\
Total soluble solids (\%) & 19.20 & $80.80^{\mathrm{a}} \pm 0.288$ & $80.50^{\mathrm{a}} \pm 0.152$ & 0.172 \\
Shrinkage (\%) & --- & $40.11^{\mathrm{a}} \pm 0.057$ & $3.24^{\mathrm{b}} \pm 0.023$ & 0.193 \\
Water activity (aw) & --- & $0.623 \mathrm{a} \pm 0.017$ & $0.582^{\mathrm{a}} \pm 0.012$ & 0.08 \\
Rehydration ratio & --- & $2.63^{\mathrm{b}} \pm 0.017$ & $3.58^{\mathrm{a}} \pm 0.023$ & \\
\hline
\end{tabular}

Data are expressed as mean \pm SE. The values given represent means of three determinations. Means in the same column with different letters are significantly $(P \leq 0.05)$ different. LSD: least different significantly at $(P \leq 0.05)$ according to Duncan's multiple range test.

Table 6. Effect of puff drying method on the color index of seedless grape as compared with the conventional air drying (Means \pm SE).

\begin{tabular}{ccccc}
\hline \multirow{2}{*}{ Drying methods } & \multicolumn{4}{c}{ Hunter color values } \\
\cline { 2 - 5 } & $\boldsymbol{L}^{*}$ & $\boldsymbol{a}^{*}$ & $\boldsymbol{b}^{*}$ & $\Delta \boldsymbol{E}$ \\
\hline Fresh & 72.44 & -14.65 & 11.76 & -- \\
Air drying & $33.53^{\mathrm{b}} \pm 0.490$ & $7.40^{\mathrm{a}} \pm 0.519$ & $4.01^{\mathrm{b}} \pm 0.230$ & $50.93^{\mathrm{a}} \pm 0.571$ \\
puff drying & $48.88^{\mathrm{a}} \pm 0.375$ & $6.30^{\mathrm{b}} \pm 0.150$ & $15.01^{\mathrm{a}} \pm 0.490$ & $24.60^{\mathrm{b}} \pm 0.565$ \\
LSD & 1.674 & 0.125 & 0.173 & 0.760 \\
\hline
\end{tabular}

Data are expressed as mean \pm SE. The values given represent means of three determinations. Means in the same column with different letters are significantly $(\mathrm{P} \leq 0.05)$ different. LSD: least different significantly at $(\mathrm{P} \leq 0.05)$ according to Duncan's multiple range test.

Table 7. Texture profile analysis of dried seedless grapes by convection air drying compared to puff drying method.

\begin{tabular}{lcll}
\hline Grapes & & Air drying & Puff drying \\
\hline Hardness Cycle & $\mathrm{N}$ & 62.55 & 34.03 \\
Adhesiveness & $\mathrm{m} \mathrm{J}$ & 0.80 & 0.40 \\
Resilience & $\%$ & 0.05 & 0.12 \\
\hline
\end{tabular}

$\mathrm{N}$ : Newton, mJ: Milli joule $=$ Newton $\times$ meter $/ 1000$

Table 8. The effect of puff drying method on the antioxidant activity of seedless grape as compared with the conventional air drying

\begin{tabular}{ccc}
\hline \multirow{2}{*}{ Seedless grape samples } & \begin{tabular}{c} 
The free radical scavenging activity of fresh and dried \\
grape fruit samples \\
\cline { 2 - 2 }
\end{tabular} & \multirow{2}{*}{ LSD } \\
\cline { 2 - 2 } & $\begin{array}{c}\text { \% inhibition of DPPH } \\
\text { Fresh seedless grapes }\end{array}$ & 84.43 \\
AD-dried seedless grapes & $63.02^{\mathrm{b}} \pm 0.333$ & 1.89 \\
PD- dried seedless grapes & $65.69^{\mathrm{a}} \pm 0.375$ & \\
\hline
\end{tabular}

$\mathrm{AD}$ : conventional air drying, PD: puff-drying. Data are expressed as mean \pm SE. Values given represent means of three determinations. Means in the same column with different letters are significantly $(\mathrm{P} \leq 0.05)$ different. LSD: least different significantly at $(\mathrm{P} \leq 0.05)$ according to Duncan's multiple range test. 
Table 9. Effect of puff drying (PD) compared to the convection air drying (AD) on the organoleptic quality properties of producing dried seedless grapes (Means $\pm \mathrm{SE}$ ).

\begin{tabular}{cccc}
\multirow{2}{*}{ Sensory quality properties } & \multicolumn{2}{c}{ Dried seedless grapes by different drying methods } & \multirow{2}{*}{ LSD } \\
\cline { 2 - 3 } & AD & PD & 0.97 \\
Color & $7.08^{\mathrm{b} \pm 0.271}$ & $8.50^{\mathrm{a}} \pm 0.341$ & 0.869 \\
Taste & $8.17^{\mathrm{a} \pm 0.307}$ & $8.47 \mathrm{a} \pm 0.240$ & 1.209 \\
Odor & $7.83^{\mathrm{a} \pm 0.401}$ & $8.00 \mathrm{a} \pm 0.365$ & 0.525 \\
Texture & $7.83^{\mathrm{b} \pm 0.166}$ & $8.83^{\mathrm{a}} \pm 0.166$ & 0.778 \\
\hline
\end{tabular}

$\mathrm{AD}$ : air-convection drying, PD: puff-drying, Data are expressed as mean \pm SE. Values given represent means of three determinations. Means in the same column with different letters are significantly $(\mathrm{P} \leq 0.05)$ different. LSD: least different significantly at $(\mathrm{P} \leq 0.05)$ according to Duncan's multiple range test.

Table 10. Cost estimation for convection air drying (AD) and puff drying (PD) methods of dried seedless grapes.

\begin{tabular}{ccc}
\hline Items & AD & PD \\
\hline Depreciation. & $540 \mathrm{LE} /$ Year & $1260 \mathrm{LE} /$ Year \\
Interest on investment. & $95.7 \mathrm{LE} /$ Year & $223.3 \mathrm{LE} /$ Year \\
Taxes and insurance. & $130.5 \mathrm{LE} /$ Year & $3045 \mathrm{LE} /$ Year \\
Maintenance and labour. & $180 \mathrm{LE} /$ Year & $420 \mathrm{LE} /$ Year \\
Electricity costs & & \\
Oven drying & $6393.6 \mathrm{LE} /$ Year & $1918.08 \mathrm{LE} /$ Year \\
Compressor & & $120 \mathrm{LE} /$ ear \\
Vacuum drying & 7339.8 & $386.20 \mathrm{LE} /$ Year \\
Total costs LE / year & 320.00 & 7372.58 \\
Total production kg & 22.93 & 576 \\
Total costs LE/ kg & & 12.80 \\
\hline
\end{tabular}

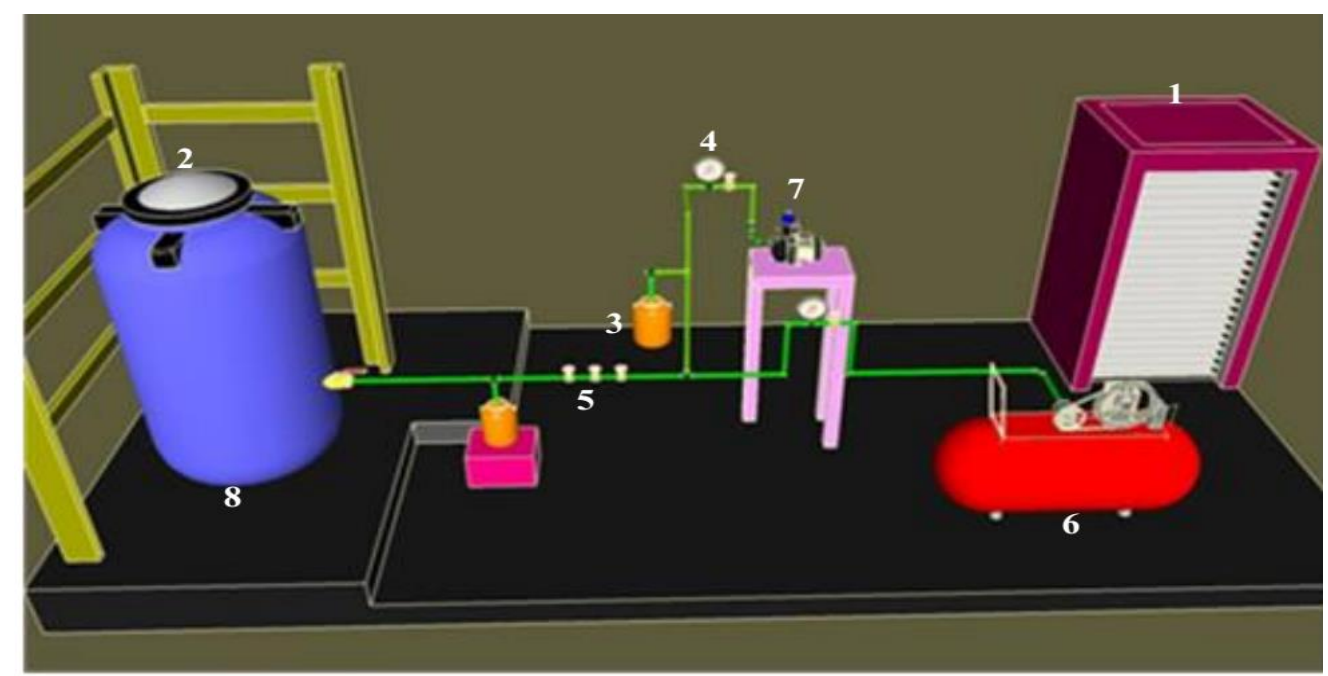

Fig. (1): isometric configuration of the puff drying system.

\begin{tabular}{|l|l|}
\hline 1- Air drying & 5- Steam generator \\
\hline 2- Vacuum tank & 6- Air compressor \\
\hline 3- Decompression valve & 7- Vacuum pump \\
\hline 4- Pressure gauge & 8- Processing vessel \\
\hline
\end{tabular}




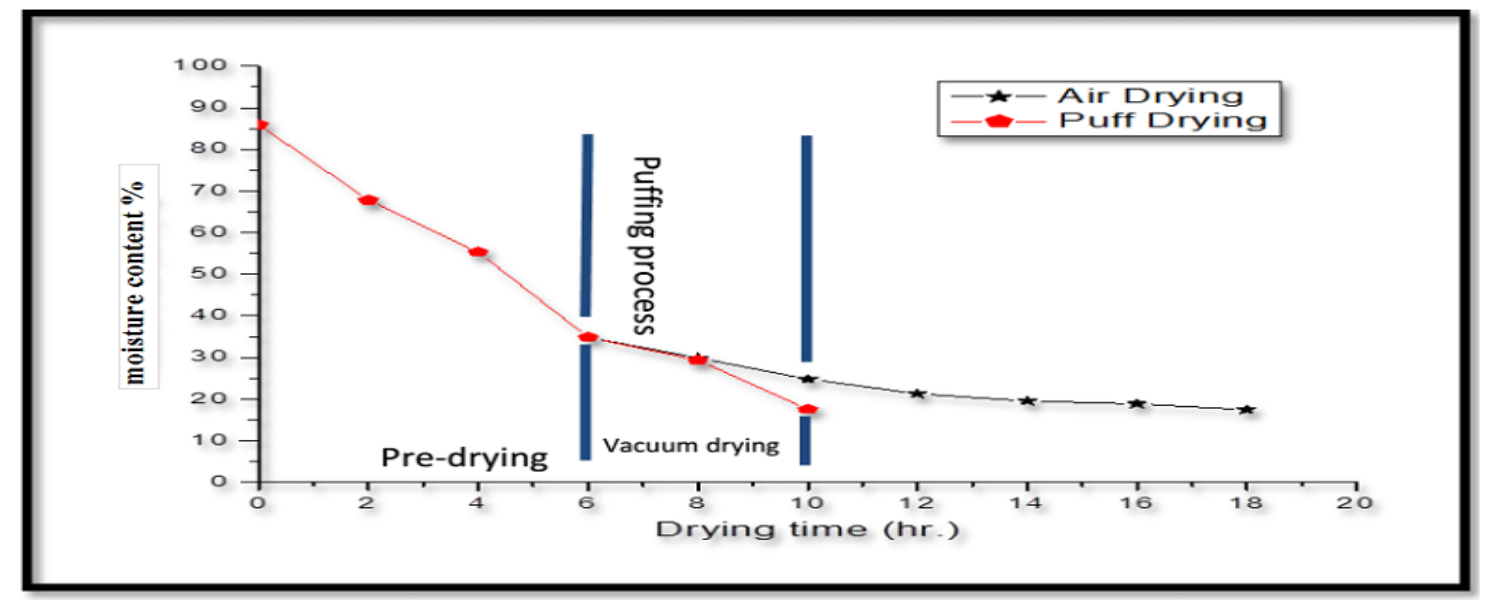

Fig. 2. The drying rate (moisture content \% and elapsed drying time) of seedless grape dried by convection air (AD) and puff drying (PD) drying methods.

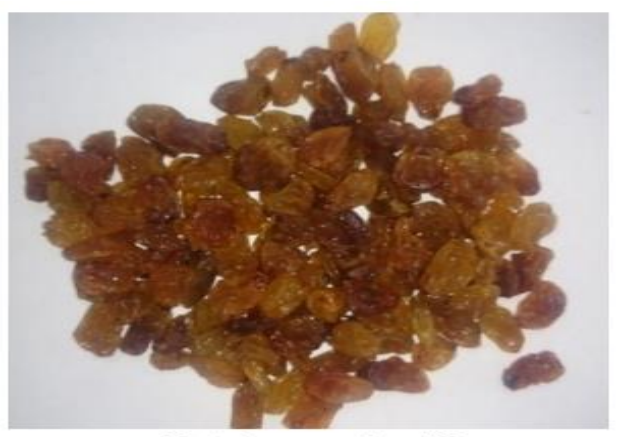

Dried grapes by AD

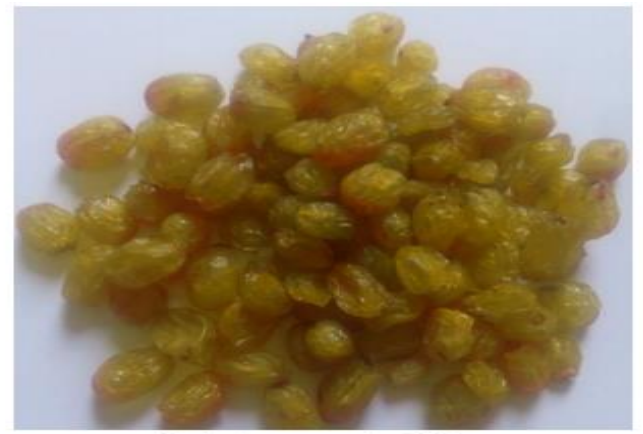

Dried grapes by PD

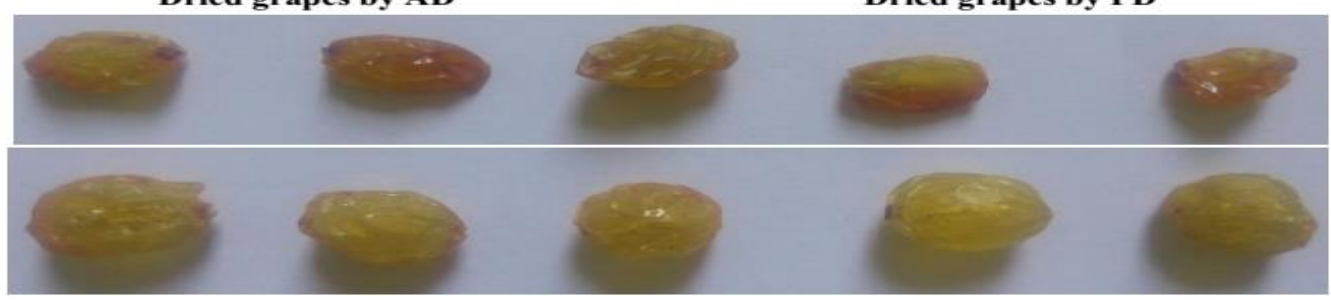

Fig. 3. Effect of convection air drying compared to puff drying method on the color of dried seedless grapes. 


\section{تأثير التجفيف بالانتفاخ على معاير جودة العنب خالي البذور مقارنة بتجفيف الممل الحراري}

$$
\begin{aligned}
& \text { مصطفي أبو الفضل محمد'، طارق حسين غانم²، ناصر البدري عبد اللاه 1، علي نصر فرج } 1
\end{aligned}
$$

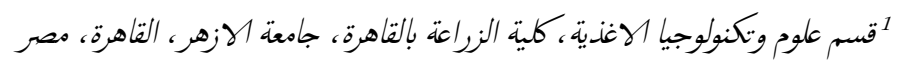

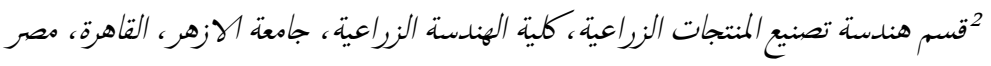

$$
\begin{aligned}
& \text { aliq11150@azhar.edu.eg البريد الإيكتروني للباحث الرئيسي: }
\end{aligned}
$$

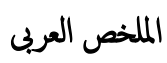

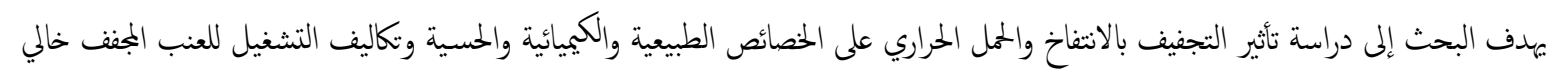

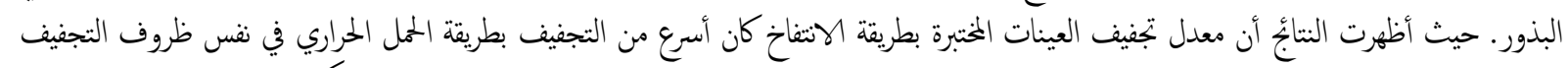

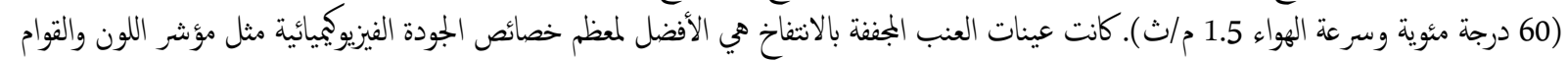

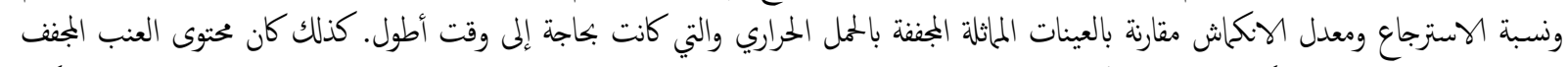

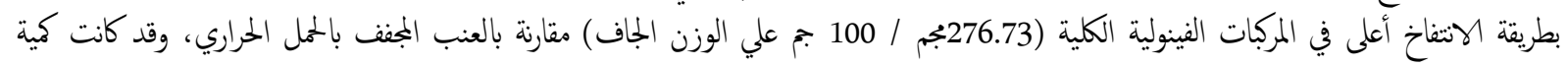

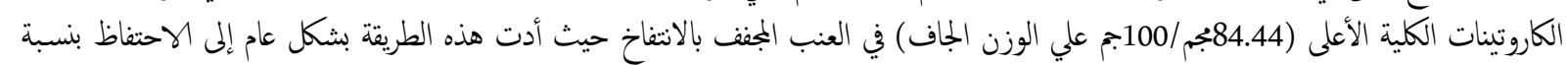

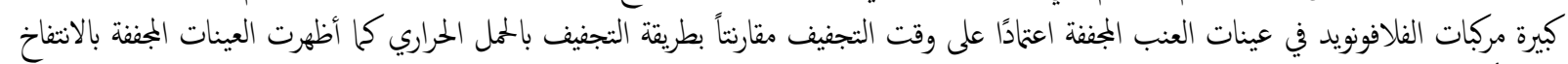

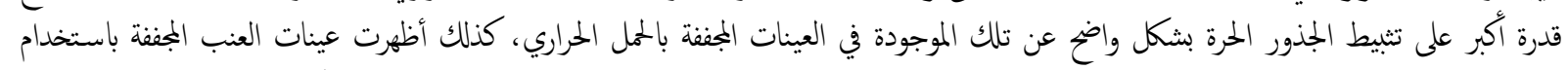

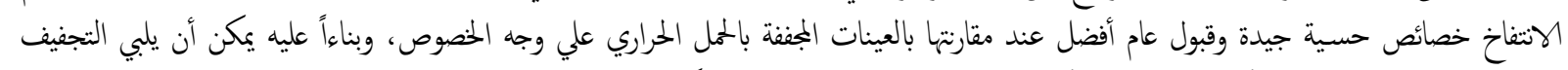

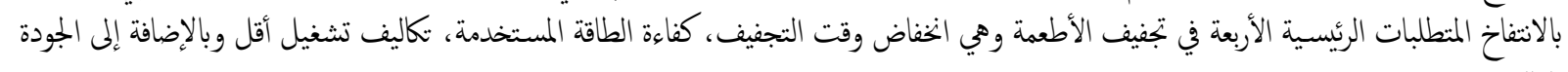

الكلمات المفتاحية: التجفيف بالانتفاخ، التجفيف بالهواء، مؤشر اللون، القوام، الجودة الحسية، المركبات المضادة للاكسدة، النشاط المضاد للاكسدة. 